\title{
MAGRIS, Aldo. Destino, providência, predestinação. Do mundo antigo ao Cristianismo. São Leopoldo: Editora Unisinos, 2014. (Coleção Ideias).
}

*Adilson Felicio Feiler

\begin{abstract}
Ado Magris é um dos mais destacados pesquisadores do gnosticismo - Lantigo. É professor de Filosofia na Universidade de Trieste, onde ministra cursos sobre religião.

O livro começa com um Prefácio em que o autor apresenta as dificuldades que teve em traduzir sua vasta pesquisa em torno ao tema do Destino reunida na obra $A$ ideia do destino no pensamento grego, em uma obra mais acessível e, ao mesmo tempo, com um caráter mais amadurecido, crítico e preciso. Vale recordar a inigualável riqueza das fontes reunidas pelo autor num único volume sobre um tema tão denso. Além de tratar especificamente sobre o destino, o autor realiza uma ponte com temas a ele ligados que é o da providência e da predestinação, percorrendo o universo do pensamento mítico, a tragédia grega, os présocráticos e o iluminismo filosófico com Platão e Aristóteles para então adentrar no providencialismo estoico e culminar na predestinação judaico cristã em Paulo e Agostinho. Entre os temas do destino, da providência e da predestinação fica patente, pela abordagem, que longe de serem considerados temas fechados em um determinismo fatalista há uma íntima conexão com a liberdade.
\end{abstract}

\section{Destino}

O fatum, o destino, não é algo isolado, mas em ligação a um vaticínio sobre o futuro, ao porvir. Daí o termo fatum derivar de Fada, a deusa

\footnotetext{
*Doutor em Filosofia, Professor da Unisinos. <feilersj@yahoo.com.br>.
} 
que assumiu a função de parturiente, padroeira dos obstetras, capaz de prever o fado, que é todo o percurso da vida do indivíduo. Os próprios deuses estavam submetidos ao fado, porém nesta mesma situação profetizavam o futuro, pronunciavam a sorte e enviavam aos homens o seu destino. Por isso, o destino é o enviado, que em alemão se chama Schicksal. Este mesmo destino, vaticinado pelas moiras, revela a finitude da natureza daqueles que o recebem, inclusive os deuses. Nos textos de Homero o destino, como sorte de cada indivíduo, não é tido como algo rigorosamente determinista, pois os eventos todos podem ser concebidos em movimento, dentro de um programa universal. A adoção posterior do destino pelo Cristianismo é concebida como algo normativo ou punitivo, a serviço da providência divina. Esta, contudo, não é um poder incontrolável, externo e que oprime, mas algo que está no interior de cada um, aquilo que se é e se escolhe ser.

O destino na tragédia grega tem, em Dionísio, pela dialética entre o eu e o outro, o visível e o escondido, a verdade e a aparência, a sua máxima expressão na máscara, o evento da universalidade como totalidade aberta. Este aspecto da tragédia grega é retomado pelo romantismo, no qual o ser humano "decide", porém dentro do conjunto da lógica divina ou fatal das coisas. Mesmo na tragédia grega "Deus" e "destino" são sinônimos, mostrando que o destino não é um fator isolado, mas uma forma de manifestação do divino que se dá de maneira enigmática, numa dialética que se move da verdade à aparência: o herói trágico que, na sua emergência, se depara com o "tarde demais". Hölderlin, um grande expoente do romantismo alemão, entende o trágico como a fusão do ser humano com a totalidade. Nietzsche, inclusive, constrói sobre a ideia do trágico uma concepção filosófica inteira. Na visão trágica hegeliana o saber aparente se deixa arrancar do seu verdadeiro para que apareça o verdadeiro em si, como natureza heroica. Em Nietzsche a tragédia sofrida não é tida como simples catástrofe, mas como algo que tem, no seu destruir-se, a sua realização. Por outro lado, Platão em seu positivismo da verdade, que é fonte da certeza, propõe uma reflexão filosófica antitrágica.

A sofia, também desempenha um papel importante na tragédia, correspondendo àquela necessidade individual de ver, ou saber sobre o mundo e si mesmo, também apresentando uma formulação conceitual do destino, ou seja, abrindo uma fenda na aparente confusão do caos da qual resulta uma sucessão de eventos preestabelecidos em uma lógica, no destino do seu concretizar-se, na fatalidade da sucessão teogônica (Ananké). Nessa fatalidade vai se atravessando limites (poros) que nada mais é senão uma experiência, Erfharung, cuja raiz é Fahrt, viagem, pois fazer uma experiência equivale a viajar até o princípio (ápeiron) e 
descortinar a fysis, uma totalidade omni-abrangente, um organismo vivo que, na metáfora do círculo, é governada pelo destino para alcançar a perfeição, a integridade e o equilíbrio. No processo de alternância dos contrários vai aparecendo a totalidade na sua verdade, como aparência, eis como o espírito da tragédia heraclitiana compreende o destino. Por isso, este se caracteriza como contrários que se enfrentam, num embate que não ocorre por acaso, mas é orientado por uma lei e uma necessidade, como um princípio cósmico que define limites aos seres, colocando-os na perpétua instabilidade do conflito, em meio a um drama trágico. Este drama, para os fisiólogos se dá através de uma circularidade cósmica, que é um processo dinâmico, em que o início está ligado ao fim, denominado por Nietzsche de "eterno retorno": a cada epiciclo findado decorre a destruição para daí dar espaço a um novo nascimento e, assim, infinitas vezes a fysis, como unidade global em movimento, vai perfazendo inúmeros epiciclos. Cada intervalo desta harmonia geral, que é uma espécie de oitava, os fenômenos serão reapresentados não exatamente como foram. Pois, pelo contrário, seria apenas mera eterna repetição do idêntico, não podendo justificar a responsabilidade ética das ações dos seres humanos. Da sequência de cada destruição segue, sempre, um desenvolvimento diferente, e não uma mera repetição. Se em Heráclito o destino se caracteriza como um princípio de regularidade física, em Parménides é uma consequência lógica estabelecida para se pensar o todo. A circularidade do retorno nos conduz à busca da verdade, não como algo a ser descoberto, mas construído e reconstruído de acordo com uma racionalidade (logos), uma necessidade (ananké) da fortuna (tyché). O estoicismo, escola sucessora da escola de Atenas, caracterizase basicamente como a escola do viver bem conforme o logos, cuja ordem se manifesta na natureza. Daí a necessidade de se adequar a ela, por um princípio racional universal, cuja eficácia manifesta-se como destino. O destino é, assim, uma instância superior em relação ao conflito entre liberdade e necessidade, porém não é contrário à liberdade. Contudo, há uma parte que deve ser entregue ao destino, que suportamos assim como é, frente ao qual nada se pode fazer para modificar. Constitui-se o destino, mais que uma fatalidade, um projeto de vida ao qual devemos aderir mais pelo coração que pelo cérebro. Portanto, o amor ao destino vai ao encontro da fórmula "amor fati" que utiliza com outros matizes. Discordamos dessa interpretação, pois amor fati em Nietzsche nada mais é senão amor ao destino, acolhida jubilosa.

O destino não é um mecanismo externo mediante o qual somos meros expectadores passivos, como uma potência que age contra os seres humanos; este é sim uma lógica que coliga os atos humanos espontâneos em uma totalidade; e dentro deste processo fatal o ser humano não pode 
deixar de empenhar o seu papel, a sua aprovação pessoal. Por isso, o destino conta com a iniciativa humana, o seu caráter (ethos) que funciona como um princípio ativo; diante disso a liberdade é considerada como algo que se conquista cotidianamente, a cada intervalo da circularidade cósmica, que ganha sentido como parte orgânica de um todo composto pelas causas eternas entre passado, presente e futuro. Esta totalidade cósmica é o ser, que não se constrói e sim se revela, reconstrói e repete, já que está implícito desde sempre segundo o destino: a lógica que coliga os vários momentos da totalidade orgânica.

\section{Providência}

Se, para os fisiólogos, a verdade aparece por trás da aparência, movida pela força do destino, para os iluministas gregos, os modernistas da Antiguidade, a verdade não é imediata mas dado fatual que empenha competência prática: o saber e a técnica. Assim, a concepção iluminista da experiência articula três fatores: a iniciativa humana (techné), a regularidade da natureza (ananché ou fysis) e a fortuna, o acaso (tyché). Desprovida de qualquer motivação reconhecível ao raciocínio humano, (a verdadeira alma do mundo do iluminismo) essa articulação opera como um destino inato a determinar a concretização na vida, a sua índole (ethos), faz surgir a concepção nascente de providência. Se, por um lado, a técnica em tudo procura reduzir o poder da necessidade e o arbítrio da fortuna, a necessidade e o acaso, por outro, põe limites à pretensão humana de dominar o mundo, já que o ser humano está inserido em uma ordem prefixada das coisas geridas pelo destino. Contudo, o destino não é mais aquela explicação omni-abrangente, pois rivaliza com a iniciativa humana enquanto techne, que não é propriamente uma liberdade, mas o ambiente do ser humano onde este se encontra dependente. É com Sócrates, contudo, que a techne é considerada com otimismo, introduzindo no pensamento ocidental a antítese "liberdade-necessidade". Com Platão a estrutura lógico-matemática do real toma o lugar do destino. O bem viver (a convivência civil ordenada) para Platão depende do correto equilíbrio entre techné, tyché e ananké. Para Aristóteles, antes de mais nada, é preciso distinguir o que é substância daquilo que é acidente, para assim buscar observar como e porque os respectivos acidentes vêm a suplantar a substância. O campo da fysis é constituído pelo devir, de modo que tudo é pervadido pela relação potência (dynamis) e ato (enérgeia). Neste processo de devir a dynamis é sempre uma iniciativa humana autônoma em que a necessidade está sempre subordinada à finalidade. Parece, todavia paradoxal que o conceito de Providência tenha a sua origem no contexto do iluminismo grego, em que o ser humano é a medida de 
todas as coisas, pois é o mesmo ser humano que, com base nas próprias exigências, vê e provê os fenômenos naturais seguindo modalidades que lhe são intrínsecas. Em síntese, a fysis é uma projeção da techné que opera sobre a base da ananché, mesmo permanecendo sempre exposta à eventualidade da tyché. Neste aspecto, o destino se caracteriza como encadeamentos causais do logos com o cosmos e a providência divina que dispõe tudo segundo a sua vontade (plano). Assim, tudo está dentro do ciclo do destino que inevitavelmente se repete, num fluxo vital.

O destino no estoicismo, embora goze de determinismo, superando inclusive demonstrações de eventos reais, apresenta uma diferença entre a necessidade da natureza extrínseca e o "destino" como instância superior de coordenação entre fatores extrínsecos e intrínsecos, na sequência rígida e imutável de eventos passados e futuros, perpassados pelo filigrama cósmico que é o destino. Neste período da modernidade da antiguidade também a inexorabilidade do destino esteve ligado a práticas divinitórias e a astrologia (horóscopo). O nexo incindível com a astronomia imprime a fatalidade, a determinação férrea e inexorável dos eventos na terra por parte dos astros. Com isso, a vida de um indivíduo fica inteiramente preestabelecida desde o seu nascimento. Contudo, esse cunho fortemente fatalista difere da ideia de destino, pois o fatalismo coloca o indivíduo numa posição de mera passividade diante dos eventos que se sucedem. Embora a astrologia seja questionada pela sua inexorabilidade, passa a ser incorporada pela noção de providência, típica em diversas religiões.

Todas as concepções deterministas estão alicerçadas na relação causa-efeito, contudo o livre arbítrio corresponde a possibilidade de o sujeito realizá-la ou não, como é o caso do aristotelismo. Na concepção estoica, apesar de as ações humanas enquadrarem-se na lógica do destino, este não consiste numa obrigação externa, mas uma autodeterminação, em virtude da própria natureza. Assim, conseguirá atingir a serenidade para além de conflitos consigo mesmo, resultantes da incapacidade de autodeterminação. $O$ epicurismo abre para um espaço de liberdade constituído pela techné, combinada pelo autocontrole do sujeito e pela influência da educação externa, a livre escolha humana e a causalidade do devir (tyché). Contudo, o determinismo monista estoico ao negar que o ser humano é o único responsável pelas suas ações, retira o fundamento do ser humano, favorecendo a preguiça e a submissão. Aristóteles vai enfrentar esta posição estoica afirmando que as doutrinas que minam a autodeterminação do ser humano o desresponsabilizam ocasionando consequências no plano da sociedade e do direito. Pois, nada neste mundo pode ser determinado: a própria necessidade da natureza e diversos fatores imprevisíveis se põem contra o destino. Assim, se o ser humano 
é o princípio das ações, lei e destino são incompatíveis. O estoicismo fundamenta a liberdade na capacidade humana de se realizar o que é concreto. Xenócrates foi o primeiro filósofo grego a escrever sobre o destino. Segundo ele, o destino é uma normativa ética que o ser humano deve respeito, bem como respeito a sua livre escolha. O destino, aqui, limita-se à esfera da práxis moral. Mas na tese dos platônicos o destino é a lei e o ser humano é o princípio totalmente autônomo de suas ações, a sua liberdade. Contudo, entra em jogo com a noção de liberdade humana, o problema da providência divina, portanto o jogo entre liberdade e destino.

A concepção platônica de alma é chave para a compreensão da providência divina, pois esta é o princípio do movimento. É Deus quem viabiliza a prática da virtude ou o vício; a responsabilidade fica a critério da escolha humana. É este pensamento providencialista platônicoestoico que posteriormente é assumido pelo Cristianismo, e a providência entendida é também logos e destino, pois reconhecer a providência é aceitar o destino. Enquanto, para o estoicismo, a providência é a lógica interna do curso do mundo, para o platonismo é um ente externo ao mundo. Para este último, o destino está subordinado à providência. Esta mentalidade vem de encontro do Deus dos hebreus e dos cristãos, um poder que ultrapassa as forcas cósmicas, de modo que o plano divino prevê todos os acontecimentos e suas fatais consequências. Se o destino atribuído por Deus jamais poderá ser diferente, qual o espaço da liberdade humana como fator que é expressão do eu? Daqui decorre uma relação difícil entre ética e destino.

\section{Predestinação}

No contexto cristão da providência deriva-se, também, um outro conceito importante em nosso estudo, o de predestinação, que diz respeito a uma trama de coisas postas para além da esfera do ser humano; é uma decisão tomada por Deus em relação ao ser humano. Assim, tanto o destino quanto a predestinação têm que defrontar-se com o mesmo problema, o do espaço da autonomia do ser humano. Na dinâmica judaica a liberdade é reservada ao plano do reconhecimento do senhorio do Deus criador, com poder de tomar decisões, aí está o contexto da liberdade humana. Os livros de Jó e Eclesiastes conservam similaridades com a tragédia grega, segundo o qual cada coisa e cada situação tem o seu próprio tempo delimitado por um fim inevitável que fatalmente acontece. O destino que é inserido na relação entre Deus e o ser humano, é a porção atribuída como a moira (tyché). Contudo, ao lado da predestinação entra a exigência do livre arbítrio, de modo que a responsabilidade do ser humano depende unicamente de sua escolha 
pela virtude e não pelo vício, virtude esta que é plantada no mesmo ser humano por Deus. Enquanto os saduceus negavam o destino, alegando que tudo estava no ser humano, os fariseus o admitiam, de modo que tudo dependia do destino e de Deus. Contudo, a ação de agir, ou não, está no ser humano. Assim, embora exista a predestinação do justo há também os méritos para os quais exige o responsável exercício da liberdade. Um gênero literário bastante difundido no séc. III a. C. é a apocalíptica, segundo a qual os anjos, seres intermediários entre os seres humanos e Deus, dirigem os destinos. As tábuas celestes são, portanto, uma metáfora típica da apocalíptica, segundo a qual no céu estão escritos os nomes dos justos desde a eternidade. Portanto, essa eleição divina dos justos inspira-se no profetismo, o pequeno resto de Israel. Neste sentido, a predestinação é a expressão fundamental da autoconsciência sectária, que instaura o destino entre o bem e o mal, produzindo assim a história. E Deus governa a história em seu domínio universal, o que corresponde ao destino. É claro que existe, nesse processo, o empenho humano, em que Deus permite que este mantenha seu agir livre. Aqui entra a Teologia do Pacto entre Deus e o ser humano, típica de antigas fórmulas qumrânicas e das cartas paulinas em que, de um lado, está a justificação e a predestinação e, de outro, a exigência rigorosa de uma práxis moral. Contudo, a justificação é apenas obra de Deus, o qual não depende de qualquer ato humano, mas sim de um reconhecimento por parte do crente na pessoa de Jesus Cristo como Salvador; e é por isso que o justo viverá pela fé, mediante a graça se inicia a ruptura com o Judaísmo, do qual deriva o Cristianismo nascente.

Em Paulo o Cristianismo tem sua marca principal, guiada pelo absolutismo da graça e a abertura a um uso seletivo da cultura grega. Desta última provém a gnose, que é o reconhecimento do ser humano em Deus e o mútuo reconhecimento no ser humano. É Cristo quem traz a salvação, ou seja, traz a gnose, mediante a fé do crente, a condição intrínseca (ousía), uma natureza, (fysis) para se elevar aos pneumáticos. Neste processo de predestinação gnóstica se exclui o ideal iluminista da autonomia do sujeito. Com o tempo o Cristianismo, pela influência do iluminismo grego e hebraico, entra num período de filosofização . Assim, como em muitas formas de gnosticismo, uma rigorosa ideia de predestinação não existe, já que a salvação depende do empenho moral do ser humano. Neste contexto, Agostinho, mediante uma releitura cristã de Platão afirma que a salvação do cristão depende da fé, pelo livre arbítrio, que é obra da graça. Assim, se a salvação é em última análise, a obra da graça, então não é possível falar em predestinação divina. Mas é uma predestinação da graça a determinar o caráter e a práxis humana e não algo exterior; sua conduta é governada pela escolha que depende 
da vontade, mas é uma vontade que quer, algo que deveria ter poder para querer e não tem, e é aí que reside a sua falta original: o poder de querer. Logo, na interpretação agostiniana do Cristianismo há um nexo entre o destino (livre arbítrio) e a predestinação (da graça).

Assim, por mais que o determinismo fatalista, do qual se expressa o destino desde a mitologia, passando pela antiguidade moderna e confluindo no pensamento cristão, tenha muitas vezes sido considerado como um determinismo inexoravelmente fechado, é possível verificar que este tem dado o devido valor na autonomia do ser humano, que é a tese do autor e ao qual manifestamos nosso assentimento. Pois o destino, que é essa condição do ser humano, lançado diante do fato, exige dele que atue sobre este, um projeto de vida que acolhe o fato, um porvir, pois é assim que ele mostra o seu caráter, seu ethos. Da mesma forma, sua posição diante da providência, nada estranha ao ser humano, reconhece a parcela humana de responsabilidade e, finalmente, a postura do ser humano diante da predestinação, em que lhe é reservada a capacidade de optar livremente potenciado pela graça. Logo, o destino, a providência e a predestinação somente encontram a sua razão de ser no espaço da liberdade do ser humano, que age para constituir um projeto de vida dando seu assentimento, com amor, ao fatum.

\section{Endereço postal:}

Escola de Humanidades

Universidade do Vale do Rio dos Sinos

Av. Unisinos, 950 - Cristo Rei

São Leopoldo, RS, Brasil

Data de recebimento: 29/03/2015

Data de aceite: 30/03/2015 